\title{
Pengaruh Kelengkungan Sudu Terhadap Kinerja Turbin Angin Savonius
}

\author{
Jamal Jamal $^{1, a}$, A. M. Shiddiq Yunus ${ }^{1}$, Lewi Lewi ${ }^{1}$ \\ ${ }^{1}$ Jurusan Teknik Mesin, Politeknik Negeri Ujung Pandang, Jln Perintis Kemerdekaan Km. 10 Makassar 90245 Indonesia \\ a jamal_mesin@poliupg.ac.id
}

\begin{abstract}
Savonius wind turbine is one of the wind turbines that is more widely used for low energy needs, with more energy needs, this turbine type is very feasible to be developed. This research aims to improve the performance of Savonius wind turbines with variations in turbine blade curvature and variations in wind speed. The research method is a laboratory experiment on the fan test, the blade curvature test variation is $1 R ; 1.5 R$ and $2 R$, another variation is the wind speed which are $4.0 ; 5.5 ; 7.0$ and $8.5 \mathrm{~m} / \mathrm{s}$. The experiement results shows that the greater the wind speed, the input power, air mass flow velocity, power output, and efficiency will be even greater; the greater the load force on the turbine shaft, the torque on the turbine shaft will also be greater; the relationship of force loads to power output and turbine efficiency is to construct a parabolic curve; for the same wind speed, the $2 \mathrm{R}$ turbine has the lowest rotation, power output and efficiency compared to the $1 R$ and $1.5 R$ turbines; at the same wind speed the 1R turbine produces a higher rotation but requires lower torque than the $1.5 \mathrm{R}$ turbine; at low wind speeds $(4 \mathrm{~m} / \mathrm{s})$ the $1.5 \mathrm{R}$ turbine has better efficiency than the $1 R$ turbine, whereas at the high wind speed $(8.5 \mathrm{~m} / \mathrm{s})$ the $1 \mathrm{R}$ turbine has a better efficiency than the 1.5R turbine; The maximum efficiency is obtained at $89.56 \%$ in the $1 R$ curvature turbine with a wind speed of $8.5 \mathrm{~m} / \mathrm{s}$.
\end{abstract}

Keywords—Turbine; Savonius; Variation; Curvature; Blade

Abstrak-Turbin angin Savonius merupakan salah satu turbin angin yang banyak digunakan untuk kebutuhan energi rendah, dengan semakin meningkatnya kebutuhan energi maka jenis turbin ini sangat layak untuk terus dikembangkan. Penelitian bertujuan untuk meningkatkan kinerja turbin angin Savonius dengan variasi kelengkungan sudu turbin serta variasi kecepatan angin. Metode penelitian adalah uji laboratorium pada alat uji fan test, variasi uji adalah kelengkungan sudu yaitu $1 R$; 1,5R dan $2 R$, variasi lain adalah kecepatan angin yaitu 4,0; 5,$5 ; 7,0$ dan $8,5 \mathrm{~m} / \mathrm{s}$. Diperoleh hasil penelitian yaitu semakin besar kecepatan angin maka daya input, laju aliran massa udara, daya output, dan efisiensi akan semakin besar; semakin besar beban gaya pada poros turbin maka torsi pada poros turbin juga akan semakin besar; hubungan beban gaya dengan daya output dan efisiensi turbin adalah membentuk kurva parabolik; untuk kecepatan angin yang sama maka turbin $2 R$ memiliki putaran, daya output dan efisiensi yang terendah dibandingkan turbin $1 R$ dan 1,5R; pada kecepatan angin yang sama turbin $1 R$ menghasilkan putaran yang lebih tinggi tetapi cenderung memiliki torsi yang lebih rendah dibandingkan turbin 1,5R; pada kecepatan angin yang rendah $(4 \mathrm{~m} / \mathrm{s})$ turbin $1,5 \mathrm{R}$ memiliki efisiensi yang lebih baik dari turbin 1R sebaliknya pada kecepatan angin yang tinggi $(8,5 \mathrm{~m} / \mathrm{s})$ turbin $1 \mathrm{R}$ memiliki efisiensi yang lebih baik dari turbin 1,5R; efisiensi maksimum diperoleh sebesar 89,56\% pada turbin kelengkungan $1 \mathrm{R}$ dengan kecepatan angin $8,5 \mathrm{~m} / \mathrm{s}$.

Kata Kunci-Turbin; Savonius; Variasi; Kelengkungan; Sudu.

\section{Pendahuluan}

Turbin angin dapat dibedakan atas dua kelompok besar yaitu horizontal axis wind turbine (HAWT) yaitu turbin angin yang poros utama sejajar dengan arah datangnya angin, jenis turbin angin yang lain adalah vertical axis wind turbine (VAWT) yaitu turbin angin yang poros utama tegak lurus dengan arah datangnya angin. Turbin angin Savonius merupakan salah satu turbin angin yang termasuk dalam kelompok vertical axis wind turbine.

Turbin angin adalah alat konversi energi angin menjadi energi mekanik, tetapi tidak semua energi angin dapat dikonversi menjadi energi mekanik [1] disebabkan adanya faktor rugi-rugi energi. Energi mekanik turbin biasa juga dinamakan dengan energi output turbin.

Hal menarik dari turbin angin savonius serta jenis vertical axis wind turbine lainnya adalah dapat berputar walaupun arah angin berubah-ubah karena jenis turbin ini dapat menerima angin dari segala arah.

Turbin angin Savonius memiliki konstruksi yang sangat sederhana karena awalnya hanya tersusun dari dua buah sudu setengah silinder berbentuk U. Turbin angin Savonius sangat tepat jika digunakan pada kecepatan angin rendah. 
Pengembangan turbin angin savonius telah dilakukan sejak lama, pengembangan dilakukan melalui penelitianpenelitian untuk meningkatkan kinerja dari turbin angin savonius. Penelitian yang telah dilakukan adalah dengan menambah jumlah dari 2 menjadi 3 sudu turbin [2]. Penelitian lainnya yaitu dengan variasi jumlah 2, 3 dan 4 buah sudu turbin savonius tipe U [3]. Penelitian lainnya adalah menggunakan Guide Vane pada turbin angin savonius dengan variasi 2 dan 3 sudu turbin [4].

Penelitian turbin angin savonius juga dilakukan pada tipe $\mathrm{L}$ yaitu dengan membandingkan dengan tipe $\mathrm{U}$ dan dengan variasi ukuran windside [5], juga dilakukan penelitian dengan variasi 2, 3 dan 4 sudu turbin angin savonius tipe L [6], serta variasi sudut kelengkungan sudu turbin Savonius tipe L [7].

Penelitian turbin savonius juga dilakukan dengan variasi kecepatan angin yang rendah [8], juga telah dilakukan penelitian turbin savonius bertingkat dengan variasi 2, 3 dan 4 sudu turbin [9], penelitian lainnya adalah penerapan turbin angin savonius bertingkat untuk pembangkit lsitrik [10].

Penelitian yang fokus pada sudu turbin savonius juga telah dilakukan yaitu variasi 1,2 dan $3 \mathrm{~cm}$ jarak celah sudu turbin [11], juga telah dilakukan penelitian variasi panjang lengkung yaitu 5/12, 6/12 dan 7/12 lingkaran dari sudu turbin angin savonius [12].

Penelitian hibrid juga telah dilakukan pada turbin angin savonius yaitu dilakukan hibrid dengan turbin angin darrieus [13] juga telah dilakukan penelitian turbin angin Savonius untuk pembangkit listrik dengan melakukan penelitian hibrid dengan sel surya [14].

\section{Metode Penelitian}
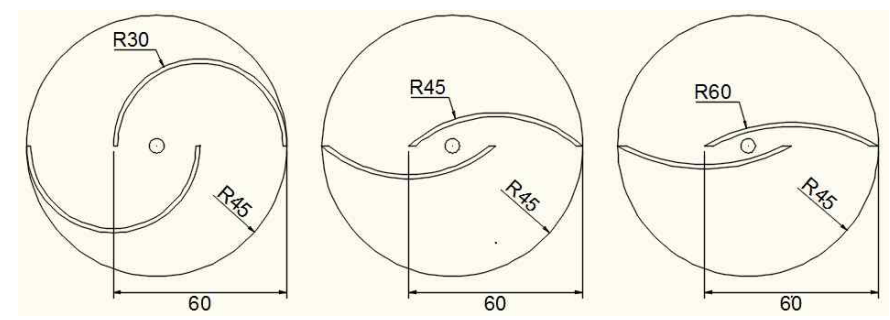

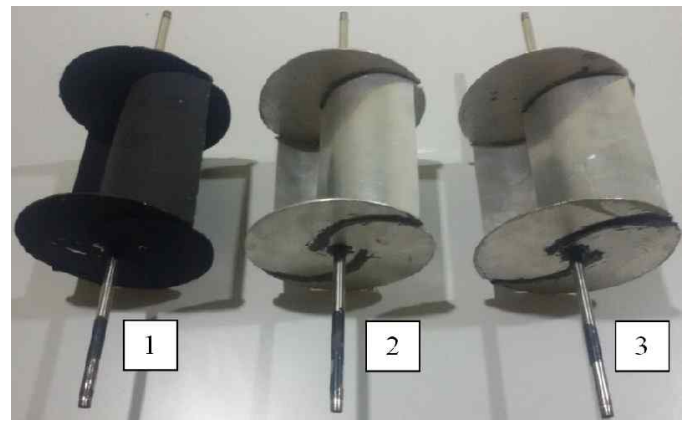

Gambar 1. Turbin Angin Savonius 2 sudu

1. Kelengkuan 1R; 2. Kelengkuan 1,5R; 3. Kelengkuan 2R

Penelitian dilakukan dengan pengujian laboratorium. Jenis turbin yang akan diuji adalah tubin angin savonius dua sudu dengan tinggi dan diameter turbin adalah 90 $\mathrm{mm}$, seperti terlihat pada gambar 1. Variasi yang dilakukan pada pengujian tersebut adalah kelengkungan sudu turbin, yaitu 1R; 1,5R dan 2R (gambar 1). Notasi $R$ adalah jari-jari kelengkungan sudu pada turbin angin savonius standar sehingga kode 1R menunjukkan bahwa turbin tersebut adalah turbin angin savonius standar, sedangkan $1,5 \mathrm{R}$ dan $2 \mathrm{R}$ berarti kelengkungan sudunya 1,5 kali dan 2 kali turbin savonius standar. Adapun jarak kedua ujung sudu turbin adalah sama untuk setiap variasi.

Pengujian dilakukan dengan menggunakan alat uji fan test pada laboratorium konversi energi mekanik jurusan teknik mesin Politeknik Negeri Ujung Pandang. Dalam pengujian juga dilakukan variasi kecepatan angin yaitu $4,0 \mathrm{~m} / \mathrm{s}, 5,5 \mathrm{~m} / \mathrm{s}, 7,0 \mathrm{~m} / \mathrm{s}$ dan $8,5 \mathrm{~m} / \mathrm{s}$. Dalam pengujian dilakukan pembebanan mekanik untuk mengukur daya output, instalasi pengujian fan test dapat dilihat pada gambar 2 .

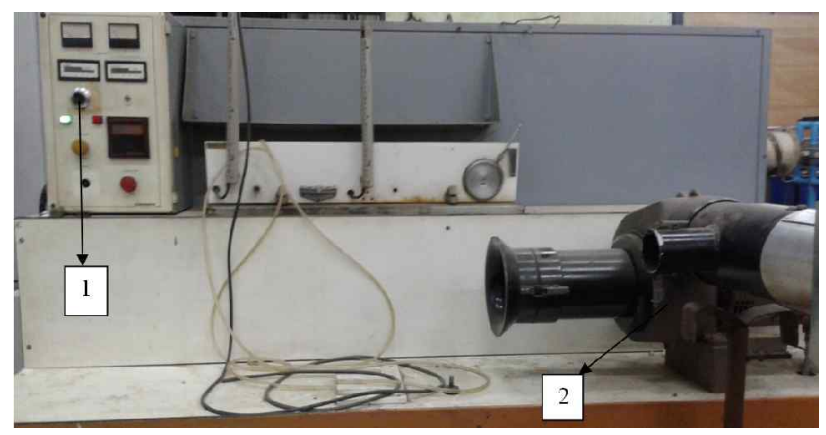




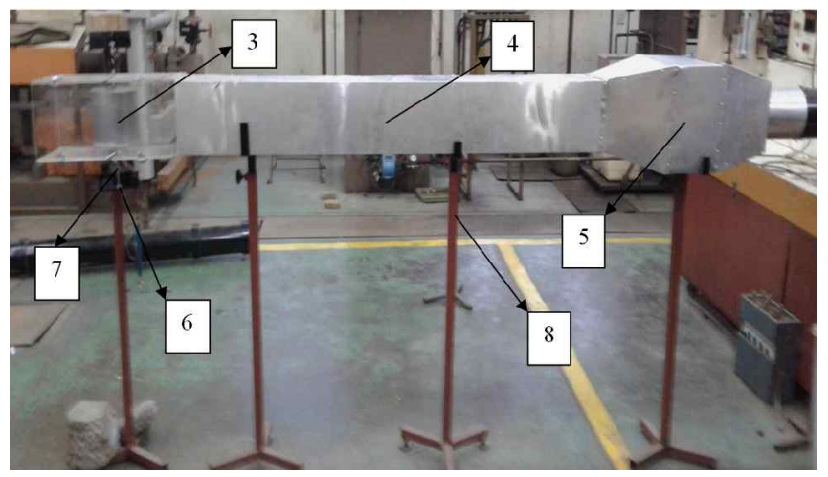

Gambar 2. Alat Uji Fan Test

(1. Pengatur kecepatan angin; 2. Sumber angin;

3. Turbin angin; 4. Terowongan angin; 5. Salurang pengarah;

6. Bearing; 7. Poros; 8. Rangka)

Dalam pengujian dilakukan beberapa pengukuran yaitu untuk mengukur kecepatan angin digunakan anemometer, untuk mengukur putaran digunakan tachometer, dan untuk mengukur beban mekanik berupa gaya pada poros digunakan pegas newton, alat ukur tersebut dapat dilihat pada gambar 3 .

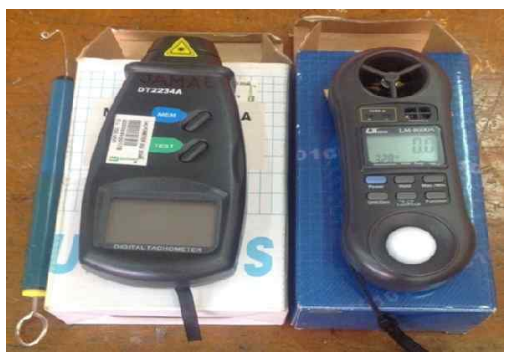

Gambar 3. Pegas newton, tachometer dan anemometer

Dalam menganalisis kinerja turbin angin savonius maka dilakukan perhitungan efisiensi turbin dengan terlebih dahulu menghitung daya angin $\left(\mathrm{P}_{\mathrm{W}}\right)$ dan daya turbin $\left(\mathrm{P}_{\mathrm{T}}\right)$ sehingga diperoleh efisiensi mekanik turbin.

$$
\begin{aligned}
& P_{w}=\frac{1}{2} C \quad v^{3} \\
& P_{T}=\frac{2 \pi n}{60} \\
& \eta=\frac{P_{T}}{P_{W}} \times 100 \%
\end{aligned}
$$

Dengan :

$$
\begin{aligned}
\mathrm{C} & =\text { konstanta Betz }=16 / 27 \\
\rho & =\text { massa jenis udara }\left(\mathrm{kg} / \mathrm{m}^{3}\right) \\
\mathrm{A} & =\text { luas daerah sapuan sudu }\left(\mathrm{m}^{2}\right) \\
v & =\text { Kecepatan rata-rata angin }(\mathrm{m} / \mathrm{s})
\end{aligned}
$$

$$
\begin{array}{ll}
\mathrm{n} & =\text { Putaran poros }(\mathrm{rpm}) \\
\mathrm{T} & =\text { Torsi }(\mathrm{Nm})
\end{array}
$$

\section{Hasil dan Pembahasan}

Pada gambar 4 terlihat bahwa semakin besar kecepatan angin maka laju aliran massa udara akan semakin besar demikian pula daya inputnya akan semakin besar.

Pada gambar 4 diperoleh hasil bahwa pada kecepatan angin $4 \mathrm{~m} / \mathrm{s}$ maka laju aliran massa udara adalah 0,11 $\mathrm{kg} / \mathrm{s}$ dan daya input adalah 0,50 watt, pada kecepatan angin $5,5 \mathrm{~m} / \mathrm{s}$ maka laju aliran massa udara adalah 0,14 $\mathrm{kg} / \mathrm{s}$ dan daya input adalah 1,29 watt, pada kecepatan angin $7 \mathrm{~m} / \mathrm{s}$ maka laju aliran massa udara adalah 0,18 $\mathrm{kg} / \mathrm{s}$ dan daya input adalah 2,67 watt, pada kecepatan angin $8,5 \mathrm{~m} / \mathrm{s}$ maka laju aliran massa udara adalah 0,22 $\mathrm{kg} / \mathrm{s}$ dan daya input adalah 4,77 watt.

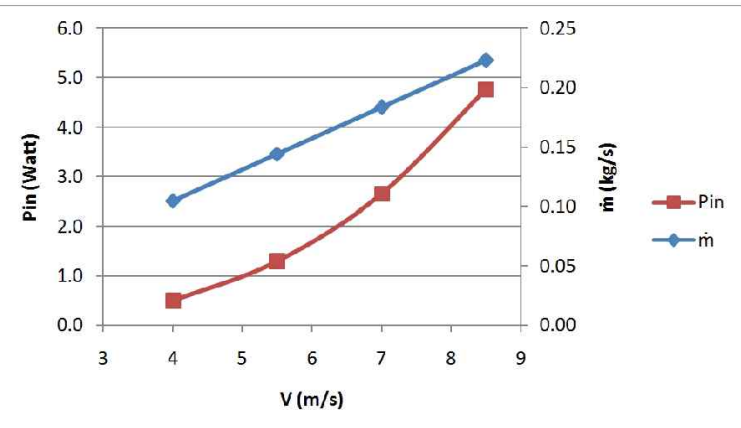

Gambar 4. Hubungan Kecepatan Udara Terhadap Laju Aliran Massa Udara dan Daya Input.

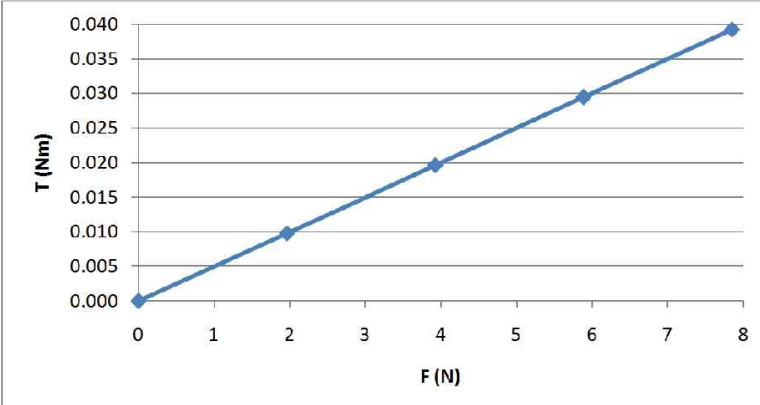

Gambar 5. Hubungan Beban Gaya Terhadap Besarnya Torsi Pada Poros Turbin.

Pada gambar 5 terlihat bahwa semakin besar beban gaya pada poros turbin maka torsi yang terjadi pada poros turbin juga akan semakin besar. Grafik yang terbentuk pada gambar 5 membentuk garis lurus.

Pada gambar 5 diperoleh hasil bahwa pada beban gaya $0 \mathrm{~N}$ maka torsi pada poros turbin adalah $0 \mathrm{Nm}$, pada beban gaya $1,96 \mathrm{~N}$ maka torsi pada poros turbin 
adalah $0,0098 \mathrm{Nm}$, pada beban gaya 3,92 $\mathrm{N}$ maka torsi pada poros turbin adalah $0,0196 \mathrm{Nm}$, pada beban gaya $5,89 \mathrm{~N}$ maka torsi pada poros turbin adalah $0,0294 \mathrm{Nm}$, pada beban gaya $7,85 \mathrm{~N}$ maka torsi pada poros turbin adalah $0,0392 \mathrm{Nm}$.

Pada gambar 6 terlihat bahwa pada pengujian menggunakan turbin dengan kelengkungan $1 \mathrm{R}$ diperoleh bahwa semakin besar beban gaya maka putaran turbin akan semakin kecil, juga dipeorleh hasil bahwa semakin besar kecepatan angin maka putaran turbin juga semakin besar. Kondisi pada gambar 6 terjadi untuk jenis turbin yang lain yaitu turbin $1,5 \mathrm{R}$ dan $2 \mathrm{R}$.

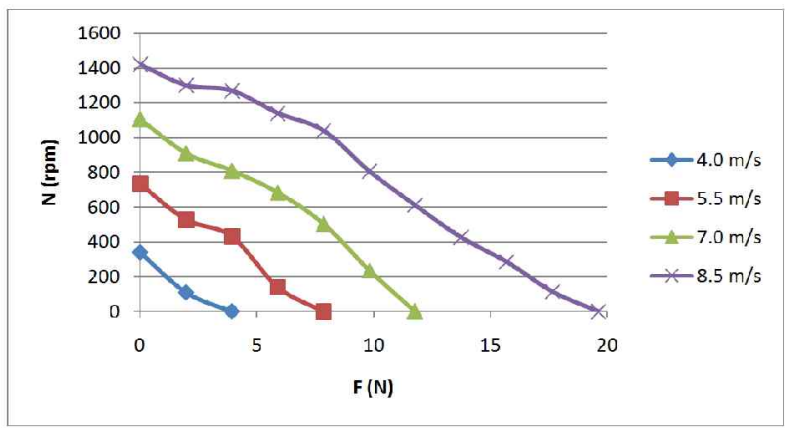

Gambar 6. Hubungan Beban Gaya Terhadap Besarnya Putaran Pada Poros Turbin Kelengkungan 1R.

Pada gambar 6 terlihat bahwa pada pengujian menggunakan turbin dengan kelengkungan 1R, kecepatan angin $4 \mathrm{~m} / \mathrm{s}$ menghasilkan putaran maksimum sebesar $339 \mathrm{rpm}$ dan berhenti pada beban 3,92 N, kecepatan angin $5,5 \mathrm{~m} / \mathrm{s}$ menghasilkan putaran maksimum sebesar $735 \mathrm{rpm}$ dan berhenti pada beban $7,85 \mathrm{~N}$, kecepatan angin $7 \mathrm{~m} / \mathrm{s}$ menghasilkan putaran maksimum sebesar $1106 \mathrm{rpm}$ dan berhenti pada beban $11,77 \mathrm{~N}$, dan kecepatan angin $8,5 \mathrm{~m} / \mathrm{s}$ menghasilkan putaran maksimum sebesar $1420 \mathrm{rpm}$ dan berhenti pada beban $19,62 \mathrm{~N}$.

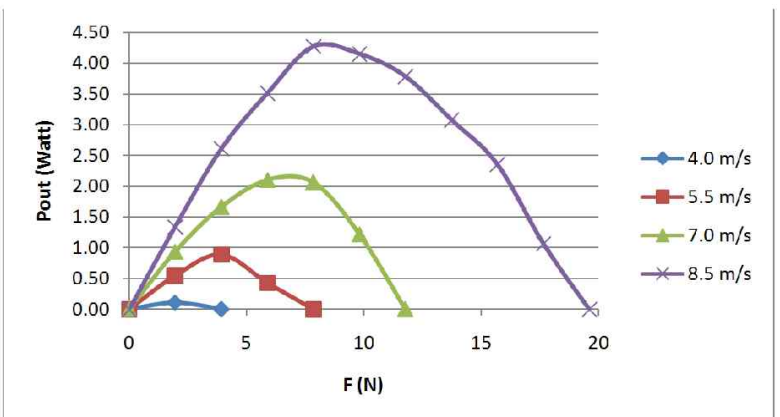

Gambar 7. Hubungan Beban Gaya Terhadap Daya Output Pada Turbin Kelengkungan 1R.
Pada gambar 7 terlihat bahwa pada pengujian menggunakan turbin dengan kelengkungan $1 \mathrm{R}$ diperoleh bahwa hubungan beban gaya dengan daya output turbin yang diuji adalah membentuk kurva parabolik, dimana pada awalnya semakin besar beban gaya maka daya outputnya juga semakin besar hingga diperoleh daya output maksimum setelah itu itu penambahan beban gaya menyebabkan daya output semakin kecil. Pada gambar 7 juga terlihat bahwa semakin besar kecepatan angin maka daya outputnya juga semakin besar demikian pula beban gaya yang mampu diterima turbin akan semakin besar. Hasil yang terlihat pada gambar 7 juga memiliki kecenderungan yang sama pada pengujian menggunakan turbin $1,5 \mathrm{R}$ dan $2 \mathrm{R}$.

Pada gambar 7 terlihat bahwa pada pengujian menggunakan turbin dengan kelengkungan 1R, kecepatan angin $4 \mathrm{~m} / \mathrm{s}$ menghasilkan daya output maksimum sebesar 0,11 watt dengan beban maksimum yang mampu diterima $1,96 \mathrm{~N}$, kecepatan angin $5,5 \mathrm{~m} / \mathrm{s}$ menghasilkan daya output maksimum sebesar 0,89 watt dengan beban maksimum yang mampu diterima $5,89 \mathrm{~N}$, kecepatan angin $7 \mathrm{~m} / \mathrm{s}$ menghasilkan daya output maksimum sebesar 2,11 watt dengan beban maksimum yang mampu diterima 9,81 $\mathrm{N}$, dan kecepatan angin 8,5 $\mathrm{m} / \mathrm{s}$ menghasilkan daya output maksimum sebesar 4,28 watt dengan beban maksimum yang mampu diterima $17,66 \mathrm{~N}$.

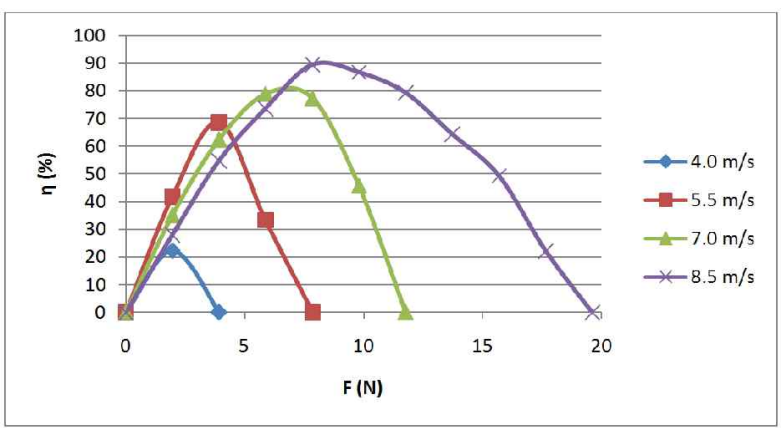

Gambar 8. Hubungan Beban Gaya Terhadap Efisiensi Pada Turbin Kelengkungan 1R.

Gambar 8 terlihat bahwa pada pengujian menggunakan turbin dengan kelengkungan $1 \mathrm{R}$ diperoleh hubungan beban gaya dengan efisiensi turbin angin savonius membentuk kurva parabolik dimana pada awalnya efisiensi meningkat dengan bertambahnya beban tetapi setelah efisiensi maksimum maka penambahan beban gaya menyebabkan efisiensi 
menurun. Terlihat juga bahwa semakin besar kecepatan angin maka efisiensi maksimum turbin angin juga akan semakin besar serta semakin besar beban gaya yang mampu diterima oleh turbin. Hasil yang terlihat pada gambar 8 juga memiliki kecenderungan yang sama pada pengujian menggunakan turbin $1,5 \mathrm{R}$ dan $2 \mathrm{R}$.

Pada gambar 8 terlihat bahwa pada pengujian menggunakan turbin dengan kelengkungan 1R, kecepatan angin $4 \mathrm{~m} / \mathrm{s}$ menghasilkan efisiensi maksimum sebesar $22,31 \%$, kecepatan angin $5,5 \mathrm{~m} / \mathrm{s}$ menghasilkan efisiensi maksimum sebesar 68,66 \%, kecepatan angin $7 \mathrm{~m} / \mathrm{s}$ menghasilkan efisiensi maksimum sebesar 78,98 \%, dan kecepatan angin 8,5 $\mathrm{m} / \mathrm{s}$ menghasilkan efisiensi maksimum sebesar $89,56 \%$.

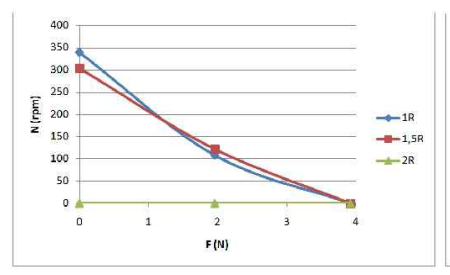

(a)

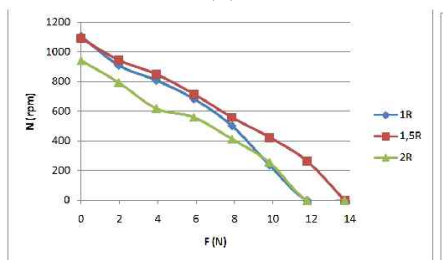

(c)

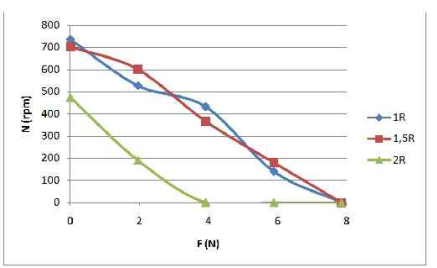

(b)

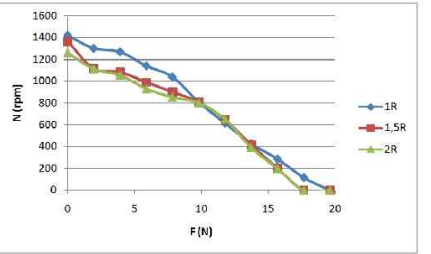

(d)
Gambar 9. Hubungan Beban Gaya Terhadap Besarnya Putaran Turbin Dengan Variasi Kelengkungan Turbin Pada Berbagai Kecepatan (a. 4 m/s; b. 5,5 m/s; c. 7 m/s; d. 8,5 m/s).

Gambar 9(a) pengujian dilakukan pada kecepatan angin $4 \mathrm{~m} / \mathrm{s}$ terlihat turbin $2 \mathrm{R}$ tidak berputar atau putarannya $0 \mathrm{rpm}$, dengan semakin bertambahnya kecepatan angin hingga $8,5 \mathrm{~m} / \mathrm{s}$ maka putaran turbin $2 \mathrm{R}$ semakin meningkat hal ini terlihat pada gambar 9(b), 9(c) dan 9(d), tetapi dari seluruh variasi turbin diperoleh bahwa turbin $2 \mathrm{R}$ yang memiliki putaran turbin maksimum terendah dan berhenti pada pembebanan terkecil dibandingkan turbin $1 \mathrm{R}$ maupun 1,5R. Pada gambar 9(a) juga terlihat bahwa turbin $1 \mathrm{R}$ cenderung memiliki putaran maksimum lebih baik dari turbin $1,5 \mathrm{R}$, akan tetapi terlihat bahwa turbin $1 \mathrm{R}$ memiliki torsi lebih rendah dari turbin $1,5 \mathrm{R}$, hal ini dapat diamati waktu berhenti turbin $1 \mathrm{R}$ terjadi pada beban lebih rendah dari turbin 1,5R.

Pada gambar 9 terlihat bahwa putaran turbin maksimum terjadi pada pembebanan $0 \mathrm{~N}$, pada kecepatan angin $4 \mathrm{~m} / \mathrm{s}$ (gambar 9(a)) putaran turbin $1 \mathrm{R}$ maksimum $339 \mathrm{rpm}$ dan berhenti pada beban 3,92 N; putaran turbin 1,5R maksimum $303 \mathrm{rpm}$ dan berhenti pada beban 3,92 N; putaran turbin 2R maksimum $0 \mathrm{rpm}$. pada kecepatan angin $5,5 \mathrm{~m} / \mathrm{s}$ (gambar 9(b)) putaran turbin 1R maksimum $735 \mathrm{rpm}$ dan berhenti pada beban $7,85 \mathrm{~N}$; putaran turbin 1,5R maksimum $703 \mathrm{rpm}$ dan berhenti pada beban $7,85 \mathrm{~N}$; putaran turbin $2 \mathrm{R}$ maksimum $474 \mathrm{rpm}$ dan berhenti pada beban 3,92 N. pada kecepatan angin $7 \mathrm{~m} / \mathrm{s}$ (gambar 9(c)) putaran turbin 1R maksimum $1106 \mathrm{rpm}$ dan berhenti pada beban 11,77 $\mathrm{N}$; putaran turbin 1,5R maksimum $1093 \mathrm{rpm}$ dan berhenti pada beban $13,73 \mathrm{~N}$; putaran turbin $2 \mathrm{R}$ maksimum $943 \mathrm{rpm}$ dan berhenti pada beban $11,77 \mathrm{~N}$. pada kecepatan angin $8,5 \mathrm{~m} / \mathrm{s}$ (gambar 9(d)) putaran turbin 1R maksimum $1420 \mathrm{rpm}$ dan berhenti pada beban 19,62 N; putaran turbin 1,5R maksimum $1368 \mathrm{rpm}$ dan berhenti pada beban $17,66 \mathrm{~N}$; putaran turbin $2 \mathrm{R}$ maksimum $1264 \mathrm{rpm}$ dan berhenti pada beban 17,66 N.

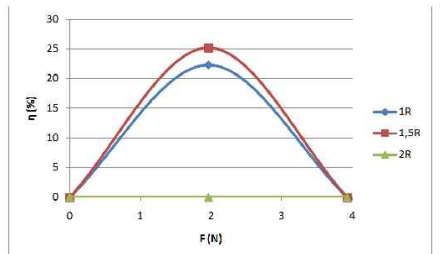

(a)

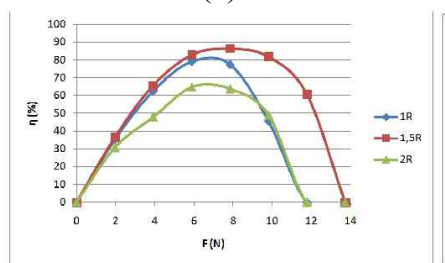

(c)

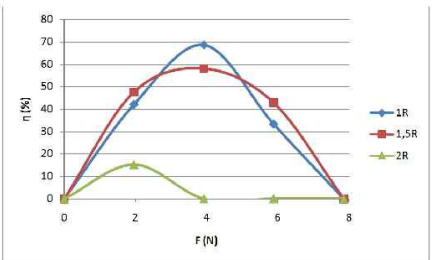

(b)

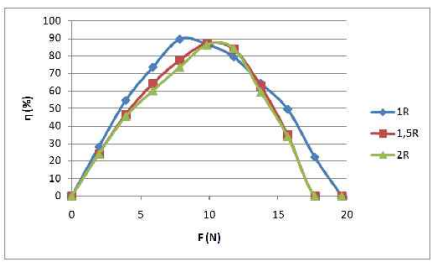

(d)
Gambar 10. Hubungan Beban Gaya Terhadap Besarnya Efisiensi Dengan Variasi Kelengkungan Turbin Pada Berbagai Kecepatan (a. $4 \mathrm{~m} / \mathrm{s}$; b. 5,5 m/s; c. $7 \mathrm{~m} / \mathrm{s} ;$ d. $8,5 \mathrm{~m} / \mathrm{s}$ ).

Gambar 10(a) pengujian dilakukan pada kecepatan angin $4 \mathrm{~m} / \mathrm{s}$ terlihat turbin $2 \mathrm{R}$ tidak berputar sehingga efisiensinya $0 \%$, dengan semakin bertambahnya kecepatan angin hingga $8,5 \mathrm{~m} / \mathrm{s}$ maka kinerja turbin $2 \mathrm{R}$ semakin meningkat hal ini terlihat pada gambar 10(b), 10(c) dan 10(d), tetapi dari seluruh variasi turbin 
diperoleh bahwa turbin $2 \mathrm{R}$ yang memiliki kinerja terendah. Pada gambar 10(a) juga terlihat bahwa turbin 1,5R lebih baik dari turbin $1 \mathrm{R}$, akan tetapi dengan semakin meningkatnya kecepatan angin hingga $8,5 \mathrm{~m} / \mathrm{s}$ maka turbin $1 \mathrm{R}$ menjadi lebih baik dari turbin $1,5 \mathrm{R}$ hal ini terlihat pada gambar 10(b), 10(c) dan 10(d). Hubungan beban gaya dengan efisiensi memiliki kecenderungan yang sama dengan hubungan beban gaya dengan daya output turbin, hal ini disebabkan daya inputnya sama untuk setiap kondisi pengujian.

Pada kecepatan angin $4 \mathrm{~m} / \mathrm{s}$ (gambar 10(a)) efisiensi maksimum turbin $1 \mathrm{R} 22,31 \%$, turbin $1,5 \mathrm{R} 25,20 \%$, dan turbin 2R $0 \%$. Pada kecepatan angin $5,5 \mathrm{~m} / \mathrm{s}$ (gambar 10(b)) efisiensi maksimum turbin 1R 68,66\%, turbin 1,5R 58,17 \%, dan turbin 2R 15,18\%. Pada kecepatan angin $7 \mathrm{~m} / \mathrm{s}$ (gambar 10(c)) efisiensi maksimum turbin 1R 78,98 \%, turbin 1,5R 86,34\%, dan turbin 2R 64,76 $\%$. Pada kecepatan angin $8,5 \mathrm{~m} / \mathrm{s}$ (gambar 10(d)) efisiensi maksimum turbin 1R $89,56 \%$, turbin $1,5 \mathrm{R}$ $87,08 \%$, dan turbin 2R 86,33\%.

\section{Kesimpulan}

Berdasarkan hasil dan pembahasan maka dapat disimpulkan sebagai berikut:

1. Semakin besar kecepatan angin maka daya input, laju aliran massa udara, daya output, dan efisiensi akan semakin besar.

2. Semakin besar beban gaya pada poros turbin maka torsi pada poros turbin juga akan semakin besar.

3. Hubungan beban gaya dengan daya output dan efisiensi turbin adalah membentuk kurva parabolik.

4. Untuk kecepatan angin yang sama maka turbin 2R memiliki putaran, daya output dan efisiensi yang terendah dibandingkan turbin $1 \mathrm{R}$ dan $1,5 \mathrm{R}$.

5. Pada kecepatan angin yang sama turbin $1 R$ menghasilkan putaran yang lebih tinggi tetapi cenderung memiliki torsi yang lebih rendah dibandingkan turbin $1,5 \mathrm{R}$.
6. Pada kecepatan angin yang rendah $(4 \mathrm{~m} / \mathrm{s})$ turbin $1,5 \mathrm{R}$ memiliki efisiensi yang lebih baik dari turbin $1 \mathrm{R}$ sebaliknya pada kecepatan angin yang tinggi $(8,5 \mathrm{~m} / \mathrm{s})$ turbin $1 \mathrm{R}$ memiliki efisiensi yang lebih baik dari turbin 1,5R.

7. Efisiensi maksimum diperoleh sebesar $89,56 \%$ pada turbin kelengkungan $1 \mathrm{R}$ dengan kecepatan angin $8,5 \mathrm{~m} / \mathrm{s}$.

\section{Daftar Pustaka}

[1] Ajao, K. R., and J. S. O. Adeniyi. "Comparison of Theoretical and Experimental Power output of Small 3-bladed Horizontalaxis Wind Turbine." Journal of American Science 5.4 (2009): 79-90.

[2] Reksoatmodjo, Tedjo Narsoyo. "Vertical-Axis Differential Drag Windmill." Jurnal Teknik Mesin 6.2 (2005): 65-70.

[3] Jamal, Jamal. "Pengaruh Jumlah Sudu Terhadap Kinerja Turbin Savonius." INTEK: Jurnal Penelitian 6.1 (2019): 64-68.

[4] Ilham Fitranda, R. O. B. B. Y. "Karakteristik turbin angin savonius 2 dan 3 blade dengan menggunakan bantuan guide vane." Jurnal Teknik Mesin 2.02 (2014).

[5] Soelaiman, F., Nathanael P. Tandian, and Nanang Rosidin. "Perancangan, Pembuatan dan Pengujian Prototipe SKEA Menggunakan Rotor Savonius dan Windside untuk Penerangan Jalan Tol." Bandung. ITB (2006).

[6] Mahendra, Bayu, Rudy Soenoko, and Djoko Sutikno. "Pengaruh Jumlah Sudu Terhadap Unjuk Kerja Turbin Angin Savonius Type L." Jurusan Teknik Mesin Fakultas Teknik, Universitas Brawijaya: Malang (2013).

[7] Dewi, Marizka Lustia. Analisis Kinerja Turbin Angin Poros Vertikal Dengan Modifikasi Rotor Savonius L Untuk Optimasi Kinerja Turbin. Diss. Universitas Sebelas Maret, 2010.

[8] Latif, Melda. "Efisiensi Prototipe Turbin Savonius pada Kecepatan Angin Rendah." Jurnal Rekayasa Elektrika 10.3 (2013): 147-152.

[9] Lewi, Lewi, and Jamal Jamal. "Analisis Kinerja Turbin Angin Savonius Bertingkat dengan Perubahan Variasi Jumlah Sudu Turbin." Seminar Nasional Hasil Penelitian (SNP2M PNUP). 2018.

[10] Yunus, AM Shiddiq, and Adhe Wahdah. "Modification and Testing of Wind Turbine with Double Savonius." INTEK: Jurnal Penelitian 3.1 (2016): 20-23.

[11] Setiawan, Andreas Andi, Rudy Soenoko, and Djoko Sutikno. "Pengaruh Jarak Celah Sudu terhadap Unjuk Kerja Turbin Angin Poros Vertical Savonius." (2012).

[12] Kusbiantoro, Andri, Rudy Soenoko, and Djoko Sutikno. "Pengaruh Panjang Lengkung Sudu Terhadap Unjuk Kerja Turbin Angin Poros Vertikal Savonius." Universitas Brawijaya. Malang (2013).

[13] Buana, Chandra, et al. "Uji Experimental Model Turbin Hybrid Savonius Bertingkat Dan Darrieus Tipe H Rotor." Jurnal Teknik Mesin SINERGI 15.2 (2017).

[14] Winarto, F. Eko Wismo. "Potensi Pembangkitan Listrik Hybrid Menggunakan Vertical Axis Wind Turbine Tipe Savonius dan Panel Sel Surya." Teknologi 6 (2013). 